\title{
Agents of Change: Academics and the Spirit of Debate at International Conferences
}

\author{
Aoife O'Donoghue
}

\author{
Keywords \\ Cambridge Journal of International and Comparative Law, international law, le- \\ gal academic conferences, individual participation in international law, feminist \\ perspectives on international law
}

\section{Introduction}

'Agents of Change', while a flattering moniker for most individuals, carries with it a set of challenges and responsibilities that acted as catalysts over the course of this journal's inaugural Cambridge conference. This article aims to digest and evaluate some of the ideas that emerged over the course of the two days while also, hopefully, adding to the debate on agency [hile beginning this paper with effusive compliments may appear clichéd, this conference unfolded in the best tradition of academic fora, generous in disagreement and debate, while rigorous in critique. As such, the organising committee in bringing together an excellent cohort of speakers and audience alike ensured everyone left Cambridge more enlightened than they arrived, and are owed due recognition. It was an honour to be asked to conclude the conference, albeit as the programme proceeded, the task of closing became ever more daunting. This intimidation emerged not only from the high quality of the discussion, but also the character in which it was conducted. Thus, this article reticently attempts to bring some of the character of that conference to this special edition of the journal.

\footnotetext{
Lecturer in Law, Durham Law School. I would like to thank Kevin J. Brown, Erika Rackley, Matt Saul and Colin Murray for their useful comments and discussion of this paper. All errors remain my own. Email: <aoife.o'donoghue@durham.ac.uk>.

1 Details of the Conference are available at <http://www.cjicl.org.uk/index.php?op tion=com_conference\&view=information $>$ [last accessed 8 October 2012].
} 
Questioning one of international law's shibboleths, the identification of the actors taking part in the international legal order, the conference facilitated debates upon some of international legal academia's fundamental characteristics. The evolution of the individual within international law, the current controversies and standing of individuals and, with perhaps some trepidation, accounts of potential developmental avenues, required the conference to cover a broad swathe of international law while keeping to its core premise. The conference's thematic considerations underlined much of the discussion around which the individual as agent served as fulcrum. This piece discusses the theme of the individual as an agent of change in the context of the papers delivered over the course of the two days, while also seeking to add to these debates by considering the wider role of the academic. More specifically, this article considers academic outputs or 'the teachings of the most highly qualified publicists of the various nations' as subsidiary sources of law and, as such, academics as developers and participators in international law. This piece particularly emphasises the role of conferences and considers whether there is a responsibility upon academia to consider the barriers to participation within the academic system and attempt their dismantlement ${ }^{2}$

This paper focuses on two aspects of the legal academic conference. First, the role of individual academic as a conference participant and, second, the individual academic's involvement in the wider international legal order. This focus on academics is not as the atomised office-dweller, thinking profound thoughts on her own, but rather as a conference participant and basic unit of any worthwhile academic event and debate; Bourdieu's homo academicus $\mathrm{3}^{3}$ The theme of this conference, the individual as an agent of change, provides a rare opportunity to consider the role of the academic as an individual participant within international law and academia and to question the role, relevance and the broader framework within which international legal conferences operate.

Academic conferences possess mercurial characters and often proceed in three modes $4^{4}$ First, the narrow subset of 'like-minded' individuals, second the broad range of perspectives brought together on a common theme that largely ignore each other's arguments and third, the broad range of perspectives on a common theme who directly engage with critiques and arguments. At times, orchestrating any of these three conference forms may be a Sisyphean task.

21945 Statute of the International Court of Justice, 33 UNTS 993 Art. 38 (1) (ICJ Statute).

3 P. Bourdieu, Homo Academicus (trans. P. Collier) (Polity, 1988).

4 For a discussion of the different types of academics, see J. Kammerhofer, 'Orthodox Generalists and Political Activists in International Legal Scholarship' in M. Happold (ed.), International Law In A Multipolar World (Routledge, 2011) 138. 
The first 'like-minded' conference remains the easiest to orchestrate while the latter two can, at times, be a matter of luck, potentially revealing the status of academic debate within a discipline or sub-genre. When the third form or 'engagement' conference materialises, outcomes such as pushing a discipline further, formulating a new branch of scholarship, or re-invigorating a sidelined debate can emerge. The value of 'engagement' conferences becomes evident when academic interaction including debating, arguing, struggling to establish concepts and deconstructing ideas while simultaneously endeavouring to convince each other of their own perspective's veracity, occurs. It is in these moments that conferences come closest to embodying a spirit of debate that underpin the possibilities of being agents of change, a point of particular import within international law.

On the first morning of the Cambridge event, the 'engagement' conference was idealised in the first exchange of opposing perspectives by two of the keynote speakers. Leading by example, Professor Crawford and Judge Cançado Trindade exchanged ideas in an open and co-operative manner which, while they evidently thoroughly disagreed with each other, was conducted in an ideal academic fashion. In setting opposing perspectives of the individual within international law and directly contradicting each other but doing so with humour, humility and mutual respect, Crawford and Cançado Trindade set the tone of not only the Cambridge conference, but arguably presented a model for academic debate. Their discussion was both strident in view and passionate in belief, but not without a willingness to engage in dialogue. Naturally, all this reads rather Socratic in tone, and while not presenting the two keynote speakers in togas, it does recall questions regarding the value and worth of academic conferences. Naturally, there are the cynical, career-minded attendance requirements, but even when this is acknowledged, the wider purpose of the academic conference should be considered. The success of the inaugural conference of this journal presents an ideal opportunity to consider this question in the context of the concluding remarks of both this special edition of the journal and of the conference itself.

This paper begins with a discussion of the theme of the conference, 'Agents of Change: The Individual as a Participant in the Legal Process' and its impact upon the academic as an individual engaged with international legal order 5 The article then moves on to consider the value of the academic conference as an embodiment of an academic ideal and follows this by a consideration of 'meetings' and what impact it can have upon academic work, while also taking

5 See supra note 1. 
a more critical consideration of some of the issues which surround the current conference landscape within international law. Finally, this paper considers the outcome of the conference itself and the legacy it has in the publications in this journal.

The aim of this paper is to consider the academic as an example of the agent of change at the core of this conference. In taking the opportunity to consider the role of the conference itself and the importance of the interaction between and among academics, it hopes to take the occasion to reflect upon how conferences can be a vehicle towards academics becoming agents of change within international law. Naturally, some of the points considered herein could apply to a much broader conference conglomeration than international lawyers, or indeed legal academia. Nonetheless, the international legal conference is the form which the author has experience of, and given the importance of an academic to international law itself in the guise of Article 38(1) of the ICJ Statute and the potential role of conferences as an avenue for the academic as agents of change, this will be the focus herein ${ }^{6}$ It is to the credit of the organisers that the aims and theme of the conference were such that these important considerations came to the fore and this paper attempts only to bring some flavour of these discussions to those unable to attend the event.

\section{Theme of the conference and the academic}

The theme of the conference 'Agents of Change: The Individual as a Participant in the Legal Process' immediately presented an issue ripe for debate 7 The individual has long been a point of debate and its contemporary character as participant, as suggested by the title of the conference, rests upon international law's historical development $\left.\right|^{8}$ This long development coupled with the high

6 See supra note 2.

7 K. Parlett, The Individual in the International Legal System: Continuity and Change in International Law (Cambridge University Press, 2011), R. Portmann, Legal Personality in International Law (Cambridge University Press, 2010), R. Higgins, 'Conceptual Thinking about the Individual in International Law', (1978) 4 British Journal of International Studies 1, G. Manner, 'The Object Theory of the Individual in International Law', (1952) 46 AJIL 428, R. McCorquodale, 'An Inclusive International Legal System', (2004) 17 LJIL 477, C. Grossman and D.D. Bradlow, 'Are We Being Propelled Towards a People-Centred Transnational Legal Order?', (1993-4) 9 Am U J Int'l L and Pol'y 1, C. Ochoa, 'The Individual and Customary International Law Formation', (2007) 48 Virginia JIL 119, J.J. Paust, 'Non-State Actor Participation in International Law and the Pretense of Exclusion', (2011) 51 Virginia JIL 977.

8 J. R. Strayer, On the Medieval Origins of the Modern State (Princeton University Press, 1979), S. Marks, 'State-Centrism, International Law and the Anxieties of Influence', (2006) 19 LJIL 
number of papers from a broad array of perspectives presented over the two days indicates the individual's importance across international law. The prescience of this theme becomes apparent upon any search of recent articles and monographs, some of whose authors were present in Cambridge ?

Before beginning such an analysis, a few definitional delineations are necessary. First, in the course of this piece, 'conference', other than direct references to the Cambridge conference (the subject of this special issue), is used as an umbrella term for inter alia, conferences, workshops, symposia, colloquia and roundtables. Using 'conference' as a general term does not imply that these sub-categorisations are valueless, but rather this article uses 'conference' to mean any event where a group of academics or, academics and other stakeholders, come together to discuss an issue with a broad intellectual intent. Further, the use of 'academic' is intended to refer to all those engaged, through the higher education system, in research and teaching. This definition of academic enables a broad interpretation aiming for inclusivity in identifying the actors engaged in conferences ${ }^{10}$ The academic conference, with the Cambridge event at the forefront, stands as the pivot upon which the role of the academic as an agent of change within international law is discussed.

While the theme of the conference points toward the importance of the issue, it also highlighted the key role of the individual academic in debate and development of international law itself. Indeed, Michael Peil's paper on his empirical work entitled, 'Most Highly Qualified Publicists: Who Are They And How Are They Used?' underlined the importance of the academic in the sense of a subsidiary source of international law, but arguably the conference highlighted a much wider understanding of the individual and, by implication, the academic in international law ${ }^{11}$ This point is developed later, however, it is

339, M. Reisman, 'Designing and Managing the Future of the State', (1997) 8 EJIL 409, D. Kennedy, 'A New World Order: Yesterday, Today and Tomorrow' (1994), Transnational Law and Contemporary Problems 329, S. Beaulac, The Power of Language in the Making of International Law: The Word Sovereignty in Bodin and Vattel and the Myth of Westphalia (Martinis Nijholf, 2004).

9 See Parlett, supra note 7, Portmann, supra note 7 and A. A. Cançado Trindade, The Access of Individuals to International Justice (Oxford University Press, 2011).

10 This is broader than the classical view offered by Coser, which focuses on a closeted male brethren 'in a community of like-minded men', L. Coser, Men of Ideas: A Sociologist's View (Free Press, 1965) 34.

11 See supra note 2, Art. 38 (1)(d). The full paper is available at M. Peil, 'Scholarly Writings as a Source of Law: A Survey of the Use of Doctrine by the International Court of Justice' (1 July 2012), Research Paper No. 12-07-03, Washington University in St. Louis Legal Studies, available at $<$ http://ssrn.com/abstract $=2115529>$ [last accessed 8 August 2012] and in this volume. 
important to highlight the role played by academics in developing legal norms. Within international law, the ICJ Statute coupled with subsequent use by the Court of academic writings makes this evident, although such use of academic work is by no means confined to international law ${ }^{12}$ In considering the role of individuals within international law, the individual scholar as part of the international legal order is embedded in its narrative.

Evidence of the breadth of academic debate at the conference was marked by the number of institutions and organisations invoked by different speakers over the course of the two days. A sample of juridical bodies called upon, including domestic courts' use of international law, proved the theme's expansive nature. The ICJ, the ICC, the ICTY, the ICTR, the Special Courts for Lebanon and Sierra Leone, the new African Human Rights Court, the Inter-American Court of Human Rights, the European Court of Human Rights, the numerous arbitrational tribunals such as ICSID and the Permanent Court of Arbitration underscored first, the range of expertise at the conference and second, brought to bear a reccurring theme: the individuals who stand in the spheres of these courts and the academics who stand as ever present critics of their operation ${ }^{13}$

Key to these discussions were both the notions of accountability and responsibility. These included the accountability and responsibilities of the actors engaged by these courts and tribunals such as judges, prosecutors and arbitrators, but also the rights and obligations of the individuals who use these institutions and organisations as applicants or prosecutees. Thus, instead of a prosaic discussion of these organisations as hermetically sealed establishments, rather the 'veil' was lifted and questions asked about what we should expect from the individuals within these institutions. These discussions also highlighted the potential role of the academic in examining these organisations. Such scholarly analysis of organisations holds academics, in an unsystematic and unregulated fashion, as a form of academic Greek chorus opining on the legitimacy and accountability of their operation ${ }^{14}$

As the vacuum of accountability within these organisations becomes more

12 In Scotland, institutional writers are utilised by the courts: T. B. Smith, 'Authors and Authority', (1972-73) 12 JSPTL 3, K.G.C. Reid, 'The Third Branch of the Profession: The Rise of the Academic Lawyer in Scotland' in H. L. MacQueen (ed.), Scots Law into the 21st Century: Essays in Honour of W. A. Wilson (W. Green, 1996) 39. For England, see R. Braun, 'Burying the Living? The Citation of Legal Writings in English Courts', (2010) 58 Am J Comp L 27.

13 See also L. Bastin, 'Amicus Curiae in Investor State Arbitration', in this volume.

14 Some of the issues relating to questions of democracy and the use of academics are considered in J.O. McGinnis and I. Somin, 'Should International Law Be Part of Our Law?', (2007) 59 Stanford Law Review 1175. 
apparent, the importance of such a role for academics becomes essential and emphasises the need to consider how the academic contributes, as perhaps an agent of change, within international law ${ }^{15}$ Besides the various judicial and arbitral bodies, the institutional structures that accompany and support these institutions, most particularly, the UN, the ICC and the ICJ, were also among the contributions. These papers brought to the fore the need to consider how individuals within these organisations affect those who use, rely (in some cases entirely) and are subject to these organisations. Whether and how we regard these organisations as bound by international law (particularly human rights and international criminal law), how these institutions react to the individual and their internal response as individuals emerged repeatedly as a theme amongst papers given by panellists 16

Particularly emblematic of this debate was Dan Saxon's keynote paper on the need to consider the live experiences within these institutional structures, particularly how the individuals within organisations react to unfolding events ${ }^{17}$ Using the current situation in Syria, Saxon highlighted both the need to see the impact of the individual within the law, but also the role of the academic in these scenarios. Most particularly, Saxon highlighted the requirement to deal with active issues, when the academic theorising must lead to an answer for individuals both inside and outside of Syria. Further, the paper emphasised the real consequences of decisions made with immediacy and the responsibility that individuals charged with making legal judgments in both the judicial and non-judicial international arena possess. Saxon's discussion was well linked to Philippe Sands' keynote paper the following day on Lemkin and Lauterpacht, reminding the conference of both the limits of academic power, but also the responsibility of what we say, what we write and our limits as individuals within international legal world.

Over the course of the two days, the variety of institutions referenced was matched only with the multiplicity of names invoked across the conference. Such references included academics, whose individual contribution to the

15 See for example, N. White, The Law of International Organisations (Manchester University Press, 2005) 189-230, A. Reinisch (ed.), Challenging Acts of International Organisations before National Courts (Oxford University Press, 2010), K. Anderson, 'What NGO Accountability Means-And Does Not Mean', (2009) 103 AJIL 170.

16 C. Michaelsen, 'The Constitutionality and Justiciability of Security Council Measures Targeting Individuals', D. Saxon, 'The Prosecutor, Defence Attorney and Judge in the International Criminal Process' and Guilfoyle's discussion of the evolution of reaction to Somali pirates: D. Guilfoyle, 'Somali Pirates as Asymmetric Actor and Agents of Change in International Law-and Governance'.

17 D. Saxon, 'The Syria Crisis and International Law: Reflections on Several Pertinent Issues'. 
international academic and legal order remains steadfast, an accomplishment which most academics probably aspire towards but few actually achieve. From Vitoria to Dworkin, from Suárez to Hart, from Gentili to Lauterpacht and from Oppenheim to a very illuminating reference to Schwarzenberger during the after-dinner speech, each name-check illustrated the variety of academic heritage available to those concerned with the abstract individual ${ }^{18}$ This heritage was continuously summoned, be that in the context of, inter alia, the judge, the prosecutor, the defence attorney, the soldier, the head of state who we wish to hold account, the child, the pirate, the terrorist, the juridical person of the state, the corporation, the NGO, the international organisation and perhaps too the individual academic. The impact these individual writers had upon the development of international law and the norms associated within it remains evident.

Nonetheless, recurring throughout the conference remained the question, which is often of prime consideration to the academic: where to begin analysis or where to start considerations of relevant material. Regarding the individual as an agent of change opens the possibility of starting with the nineteenth century and the sovereign consent based system which was the hallmark of the majority of academic debate over the nineteenth and early twentieth centuries. This was of central import to Crawford's paper ${ }^{19}$ Or should one start with the seventeenth century and discuss the era in the pre-Vattellian/Bodin penumbra, when the state was not all encompassing and the individual not embodied by it? Or perhaps go further back to antiquity to show the undulation of formulations of law:20 Alternatively, should examination begin with the creation of the UN and the establishment of what is described as the beginning of a fully fledged 'mixed actor' setting: ${ }^{21}$ As was mentioned several times during the course of the conference, where one starts, sets one's paradigm. It would not be safe to claim that any of these four alternatives or combinations thereof was agreed among the assembled group. Nonetheless, what did appear to be established was that considering the potential for an evolutionary role for the individual

18 After-dinner Speech given by Dr Roger O'Keefe (University of Cambridge) at the Gala Dinner of the Cambridge Journal of International and Comparative Law annual conference, St. Catharine's College, Cambridge, 19 May 2012.

19 See for example, L. Oppenheim, 'The Science of International Law: Its Task and Method', (1908) 2 AJIL 313 at 328.

20 See Beaulac, supra note 8, D. Bederman, International Law in Antiquity (Cambridge University Press, 2001).

21 C. Harding, 'Statist Assumptions, Normative Individualism and New Forms of Personality: Evolving a Philosophy of International Law for the Twenty First Century', (2001) 1 Non-state Actors and International Law 107. 
within international law was, at least, a possibility.

An alternative avenue for debate would be to consider the question without any historical paradigm. If a person examined the individual as participant and agent of change from coming to this conference or from considering practice, how would they perceive the state of play: $:^{22}$ Starting afresh as Suárez, Gentili, Vitoria and Grotius were able to an extent to do, writing minus any reliance upon academic legacy, what would that freedom result in? How would they consider the contemporary state of play? Would an ahistoric academic consider the individual to be the basic unit of international law? Would the terminology within which we frame our academic debate re-emerge or would an alternative, more appropriate jargon surface, suggesting that our use of language stifles debate: ${ }^{23}$ When terminology has not caught up with practice, confusion as to whether individuals are actors, subjects or objects, or indeed participants, forces academics and scholarly debate into categories which do not always reflect the nuance of what is being argued, and perhaps eschews our ability to discuss the core issues, as we are pigeon-holed into types. Which leads back to the starting point: how do individual academics contribute to such questions rather than obfuscating and confusing what would potentially be clearer to the ahistoric academic?

Yet, this ahistoric scholar would not benefit from the rich academic record that fills our footnotes and commentary. O'Keefe's after-dinner speech characterised the wealth of authority that we readily reach for when trying to articulate our own claims and assertions. Does the ahistoric academic, possessing the freedom to establish an account of the law, miss out on a wealth of academic discussion which diagnosed many of the issues alluded to at the conference and, as such, miss the opportunity to engage with the spirit of academic debate which conferences give the opportunity to do? Underestimating our inherited academic treasure trove leaves academia in a cycle of re-definition that while worthwhile in a critical analysis, is perhaps less than ahistoric analysis can bring to bear. Thus, it is necessary to ensure that academic heritage is brought to the fore without swatting academic opponents with great names from the past.

22 Naturally this has echoes of Rawls' veil of ignorance: J. Rawls, A Theory of Justice (Oxford University Press, 2009) 118-23.

23 P. Goodrich, 'Rhetoric as Jurisprudence: An Introduction to the Politics of Legal Language', (1984) OJLS 88. 


\section{Idealised academic conference and the need to engage with its spirit}

The changing character of third level education within UK academia has shifted scholarship towards a professionalisation evident across law schools, which arguably has a particular effect on international legal academics ${ }^{24}$ ' Gentlemen barristers' (and the gender connotations and effects upon the academic pool from which such dual mandate scholars were chosen that accompanies that phrase) are largely becoming absent from law schools ${ }^{25}$ Nonetheless, in some instances, international law bucks this trend, indeed Crawford and Sands are ample evidence of the continued role for the international practitioner which in other disciplines are becoming less a facet of the UK law school. The establishment of clear career routes, through undergraduate degree, Master's, $\mathrm{PhD}$ and the publication and conference circuit has shifted the trajectory of the average academic career.

Recently, Bill Bowring, focusing upon the development of a more critical approach to international law, lamented the lack of interaction between legal practice and academia ${ }^{26}$ While some evidence of interaction was clear at the conference in the shape of Crawford, Sands and Saxon, Bowring's commentary remains salient in a variety of areas within international law, particularly its practice before domestic courts. Bowring's broader point, the narrow character of critical commentary within international law, has much merit and has a bearing on the field of attendees of academic conferences. The increasing cost of a basic legal education combined with the lack of a dual mandate of practice and academia has the potential to further narrow the participants at conferences. Arguably, the support necessary to build and maintain such dual mandate careers limits the potential pool of such scholars, particularly when international legal practice, beyond domestic courts, remains restricted to a relatively small group. Potentially, the contraction of academic career paths within international law takes away from the conference as a fruitful and important avenue of academic engagement and learning, and

${ }^{24}$ F. Cownie, Legal Academics: Culture and Identities (Hart, 2004) 73-5.

25 C. Wells, 'Women Law Professors-Negotiating and Transcending Gender Identities at Work', (2002) 10 Feminist Legal Studies 1, R. Collier, 'The Changing University and the (Legal) Academic Career-Rethinking the Relationship Between Women, Men and the Private Life of the Law School', (2002) 22 Legal Studies 1.

${ }^{26}$ B. Bowring, 'What is Radical in Radical International Law?', (2012) Finnish Yearbook of International Law, (forthcoming), available at <http://ssrn.com/abstract=1982159> [last accessed 23 October 2012]. 
enables its career-orientated justifications to take centre stage. Thus, the importance of engaging and inviting non-academic lawyers to such events, as Bowring points out, becomes essential. Nonetheless, while there is not a shortage of conferences to attend, the reasons for holding such conferences, beyond professional advancement, or indeed in the era of UK REF readiness, contribution to 'environment', needs to be brought to the foreground when both undertaking to give a paper or organising a conference structure ${ }^{27}$

Arguably, academic conferences should have a number of aims. First, to ensure academics actually meet. This point will be returned to again, but this perhaps is the most critical reason and the one which the other aims stem from ${ }^{28}$ Further objectives include the furtherance of knowledge through international legal 'academic rhetoric'; to advance knowledge of a particular specialisation; and to contribute to the update of information on an area which, in our myopic academic concerns, may otherwise have passed unnoticed ${ }^{29}$ Good conferences should also expose us to perspectives on areas which we normally would not be drawn towards. Finally, a conference should give the opportunity to argue, discuss and fundamentally disagree with each other in an environment designed to further academic engagement.

As already mentioned, conferences can be categorised into three groups: the narrow subset of 'like-minded' individuals; the broad range of perspectives brought together on a common theme but who largely ignore each other's arguments; and the third, the broad range of perspectives on a common theme that directly engage with critiques and arguments. The Cambridge conference offered the best of the third category. While, generally speaking, most participants were international academic lawyers, the range of specialisations and perspectives was impressive. This was particularly evident on the second day, with a range of panels and discussions taking place around the central theme of the conference.

The maintenance of coherence among the panels on the second day

27 Research Excellence Framework, 2014 <http://www.ref.ac.uk/> [last accessed 8 October 2012]. See also Cownie, supra note 24, at 135-41. For a discussion of changing cultures in Law Schools, see E. McWilliam, 'Changing the Academic Subject' in R. Hunter and M. Keyes (eds.), Changing Law: Rights, Regulation and Reconciliation (Ashgate, 2005) 107. For a discussion of the historical variety among UK Law Schools, see W. Twining, "Thinking About Law Schools: Rutland Reviewed' in A. Bradney and F. Cownie (eds.), Transformative Visions of Legal Education (Blackwell, 1998) 1.

28 N. Gross and C. Fleming, 'Academic Conferences and the Making of Philosophical Knowledge' in C. Camic, N. Gross, and M. Lamont (eds.), Social Knowledge in the Making (University of Chicago Press, 2011) 153.

29 See Bourdieu, supra note 3, at 209. 
was a credit to the hosts, but also shone a light on the underlying purpose of hosting conferences. While all academics maintain a certain general expertise in their area, often this expertise can be in a minutia of law or theory. Often, with the exception of teaching responsibilities, the academic may be considered the opposite of the 'Jack of all trades' by being the master of one. In so becoming, academics often become blinkered and, unfortunately, unaware of the importance of other sub-genres even within the broad field where we place ourselves: public international law. This furtherance of knowledge and updating of information fulfils a key aim of re-invigorating academics' education and curiosity, which arguably should never end. Academic conferences that bring a wide range of voices together allow, at the very least, a casual interaction with areas that we naturally would not be drawn towards, but which inform an academic's perspective and, as such, are important to enable us to consider facts or areas of study which otherwise we would not naturally read or consider.

These papers, outside of an immediate interest, are important. While they may not instantaneously pique debate with every academic present, they do provide another important feature of conferences: arousing curiosity. Lucas Lixinski's paper on UNESCO was an excellent example of such a presentation 30 The political implications and impact of the individual agent within UNESCO's workings and its coupled impact upon diverse areas of international law, from the use of force to sovereignty, was an area of analysis which was eloquently brought to the attention of the general international law audience. Conferences such as the Cambridge event enable the identification of areas of research, debate or simply coming across law that otherwise academics would have little or perhaps just a sketchy knowledge of, while enabling consideration of how our own research could be improved by understanding trends in these areas. The teaching implications are also manifest as such papers facilitate the use of examples from across a wider spectrum than perhaps would naturally be touched upon in the normal course of lecturing and preparation. Gleider Hernández's paper on the ICJ judiciary entitled, 'How ICJ Judges See Their Decision-Making Role' was another example of the development of this kind of knowledge. Judges as individual agents and participants may be obvious, but the underlying tenet of the paper, understanding perspectives, raised important questions central to any academic debate. The consideration of educational background raised the process of decision-making in a context

${ }^{30}$ L. Lixinski, 'Heritage for Whom? Individuals' and Communities' Roles in International Cultural Heritage Law'. 
that brought to the fore the importance of all elements of the individual as a participant, and offered a reflection on the role of academics in informing such decision-makers.

This 'lite' exposure to other areas in international law also extends to other perspectives. As already mentioned, both Crawford and Cançado Trindade led by example in expressing opposing views in dialogue with each other. However, they were not alone in their debate on themes and issues. Virtually every panel contained competing views on the role of the individual within international law, from a multiplicity of perspectives such as jus cogens accountability, legitimacy or as law-makers ${ }^{31}$ These panel-led debates contribute to the expansion of knowledge in another, potentially more significant, manner by exposing academics to perspectives that they either had not previously considered (though most academics are loath to admit that there is nothing that they have not considered) or if they have already considered them, to re-evaluate the rational and reasoning behind these alternative perspectives.

Both of these, the exposure to aspects of law or ideas new or afresh, are reasons in themselves to maintain the practice of conferences, but both are predicated on the conference being of the third 'engagement' variety. This is not to suggest that conference organisers should necessarily set up a form of bread and circuses, where academics attend to watch a bloody exchange of views with personalities not only known to disagree, but who wholly have serious personality differences, leading the debate away from the academic into the personal. Indeed, attempts to do such should be shunned, though at times they are unpredicted outcomes of two contrasting personalities. Nonetheless, conferences should, as they did in this Cambridge event, unlock opportunities to present contrasting arguments to other academics and see what emerges from the mix of ideas. Discussing international law with those who agree with you over similar areas of research can be interesting, but arguably does not make for a conference which is academically worthwhile. This proposition leads directly to Sands' keynote paper on Lemkin and Lauterpacht, and the necessity, when possible, of ensuring that academics who do not agree meet to discuss their views.

31 For example, T. Weatherall, 'Legal Effects and Structural Implications of Peremptory Norms of General International Law (Jus Cogens)', K. Bashir and M. Janaby, 'The Right of Individuals to Take Judicial Action Against International Persons', K. Miles, 'The Role of the Claimant as an Agent of Change in International Investment Law', D. Guilfoyle, 'Somali Pirates as Asymmetric Actor and Agents of Change in International Law and Governance'. 


\section{4 'Meetings'}

Sands' paper, centring on two individual academics, opened up broader questions on the role of academics as agents of change in international law ${ }^{32}$ Focusing on Lemkin and Lauterpacht, two academics whose contribution to international law remains indisputable, Sands posed questions on the role of academics in shaping international law. Further, he incorporated queries on individuals within groups, the individuals as atomised actors and as focal points of accountability, all of which the audience eagerly engaged with. The paper opened the possibility of considering the role of academics when positioned in a particular theoretical group, how that grouping impacts upon debate and critique of work, what the categorisation should mean, as well as how much consideration should be given to the impact of categorisation upon the individual academic as an agent of change within international law. Standing alongside such questions are the accommodation and import of 'meetings'.

Rooted in the evolution of international law in the nineteenth and early twentieth centuries, the positions of individuals within international law, a point which was key to Crawford's account of the present operation of the law, was central to Lemkin and Lauterpacht's debate on piercing the veneer of state accountability for individual action. Their debate, on individual accountability within international law, set the tone for the manner in which the individual has emerged in the past half-century as a focus of international human rights and criminal law, both of which both Lemkin and Lauterpacht were instrumental in developing 33 Besides the importance in law of the individual as either part of a group or as entirely separate, which was at the heart of their academic divergence, the gulf between Lemkin and Lauterpacht's positions is indicative of the import of the individual academic within the development of international law. Sands' paper focused the conference on the need to grapple with the individual academic, and this journal's special edition enables the continuation of such a debate.

The key point in Sands' paper was that while they influenced each other's

32 P. Sands, 'The Individual as an Individual, or as a Member of the Group? Lauterpacht $v$ Lemkin, Tuesday 1 October 1946, 10am, Palace of Justice, Nuremberg.'

33 R. Lemkin, 'Genocide as a Crime under International Law', (1947) 41 AJIL 145, R. Lemkin, 'Genocide: A New International Crime, Punishment and Prevention', (1946) Revue Internationale de Droit Pénale 360, R. Lemkin, 'Genocide: A Commentary on the Convention', (1949) 58 Yale Law Journal, 1142, H. Lauterpacht, The Function of Law in the International Community (Clarendon Press, 1933), H. Lauterpacht, 'The Subjects of the Law of Nations', (1947) 63 LQR 438, H. Lauterpacht, International Law and Human Rights (Stevens \& Sons, 1950). 
work, Lemkin and Lauterpacht appear to have never actually met, thus leaving an unanswerable question on what could have emerged had they been granted an opportunity to consider their opposing ideas in each other's company. Perhaps their positions would have remained unchanged, but also a personal meeting may have strengthened either's critique of their relative positions. Arguably, this holds true for any contemporary academic debate and the critical point to take from the conference for those who seek to be academic agents of change within international law is to engage with their academic opponents directly, and when possible, in person ${ }^{34}$

Conferences enable academics to meet, to discuss, to take part in a panel, to give a keynote address, to receive an audience response, to have a personal conversation over coffee while precariously balancing a teacup, saucer, conference pack and biscuit while looking dignified, and yet engage with the other coffee-drinking academics in a open and, at times, conflicting style. It is often in meeting through introductions at conferences, or re-meeting with past acquaintances, that academics engage with those whose work they have read, relied upon, enjoyed, distrusted, become angry at, or simply perused, and allows us to engage with the person behind the article or book. Such meetings may not necessarily lead to a revelatory moment, but alongside the rationale outlined in the previous section, personal interactions can lead to better understandings of another's-and perhaps even our own-perspectives.

Of course, scholars may develop a negative view of a fellow academic at a conference and this is a risk any scholar runs when agreeing to give a paper, particularly the mounting pressure to be persuasive. Conferences enable an impression of the work of a particular scholar leading to either positive or negative prejudices. Nonetheless, such meetings de-mystify aspects of the academic process. This de-mystification holds particular relevance to those beginning their careers, particularly when certain figures who are held in reverence reveal their craft in an open and engaging manner. We are very good at, to use Sands' phrase, rarification. We build edifices. Rarification permeates any hierarchical structure. Conferences buttress elitism when keynote speakers are kept apart, at coffee or at dinner, from the attending great masses, and levels of formality become exaggerated. We thus have a responsibility to challenge our rarifications, our constructions and hopefully this conference, as all conferences should, gave those attending such an opportunity, allowing academics to engage with each other, enabling discussion and debate in a positive and constructive

34 See also Goodrich's discussion of lex amicitia in shaping ideas in P. Goodrich, 'The Immense Rumor', (2004) 16 Yale JL \& Humanities 199, at 205. 
basis, not reliant on a veneer of edited writing.

In the concluding remarks at the conference I joked about meeting a fellow delegate, Ruvi Ziegler ${ }^{35}$ In meeting over a coffee, we did the classic academic conference activity of, 'you are at X, I work with $\mathrm{Y}$ who used to be at $\mathrm{X}$ do you know them?' attempting to make a connection while joking that we were partaking in stereotypical conference behaviour. While this can, at times, be part of the much derided 'networking' aspect of conference attendance, as Sands' paper recalled, this personal connection remains worthwhile. My concluding remarks may have ended with the statement that never will it be said that like Lemkin and Lauterpacht 'Ziegler and O'Donoghue never met'. While this was intended as a joke, underlying the comedy was a broader point that conferences allow us to meet and exchange ideas. The mutual respect and friendship was evidenced by Crawford and Cançado Trindade's papers. Even though it was clear that they had failed to convince each other to change their respective minds, each emphasised the importance of discussion. If individual academics can be considered agents of change, then an exchange of their propositions and theories with their peers is essential to establishing and disseminating ideas.

\section{Barriers to participation}

While deliberating upon the rationale and structures of the international legal conference, it is incumbent upon such an endeavour to also consider some of the issues related to participation in academic conferences. These issues, in many ways, reflect the structure of modern international legal academia and, in the context of the individual as a potential participant in international law, are most readily relevant to the conference. The role of the academic in international law is important and thus the ability to participate within the academic framework is manifestly linked to the potential of academics to be agents of change. Therefore considering the available points of participation is the most obvious matter to begin with when conducting a critical evaluation of conferences.

Issues relating to contributions to legal conferences include the relative openness of participation and identity, the representation of women, the presence of ethnic minority groups, barriers to disability access and the range

35 Ziegler's paper was entitled, 'External State Protection and the Predicament of Recognised Geneva Convention Refugees'. 
of views represented ${ }^{36}$ These questions, both individually and collectively, are critical considerations that both organisers and participants should be aware of when arranging and attending academic conferences. These questions of participation are part of a much broader debate within academia, but such issues deserve continuous discussion, as equality of participation remains a persistent problem, which perhaps is at its most visible during conferences ${ }^{37}$

Arguably, this is a particularly important issue for international law. As previously mentioned, the academics or 'the teachings of the most highly qualified publicists of the various nations' are subsidiary sources of law ${ }^{38}$ This establishes an impetus among academics to consider the barriers to participation that are built-in to the academic system and attempt their dismantlement ${ }^{39}$ This should ensure that the most suitable and deserving individuals are brought to the fore and that diversity and equality are assured. While a variety of geography remains the only qualifier in the ICJ articles on judges, a broad reading of the article to include the implications of the meaning of 'highly qualified' in certain areas, such as, inter alia, development, human rights, self-determination and gender requires a much broader interpretation than simply holding a passport ${ }^{40}$ Participation in academic conferences is one method by which this can be assured, and warrants that all individuals can be participants and agents of change within international law and at least present for consideration by the ICJ as one of the most highly qualified publicists.

Both open-calls and invitation-only events are equally important in considering the role that conferences play in disseminating intellectual thought. While their comparative complications are somewhat different, the same considerations (their relative accessibility and the representation of women, ethnicities, sexual orientations, disabilities and educational backgrounds) must be borne in mind by organisers ${ }^{41}$ This is particularly relevant to international law, where

36 See Cownie, supra note 24, at 167-96.

${ }^{37}$ See Collier, supra note 25, at 15.

38 ICJ Statute, Art. 38(1).

39 See Cownie, supra note 24, at 167-96, F. C. Cownie, 'Women Legal Academics: A New Research Agenda?', (1998) Journal of Law and Society 102.

40 A similar interpretation is used for the employment of the secretariat under Art. 101(3) of the Charter of the United Nations. See also H. Charlesworth and C. Chinkin, The Boundaries of International Law: A Feminist Analysis (Manchester University Press, 2000) 81 and 176.

41 L. Louis-Jacques, 'Gaps in International Legal Literature', (2000) 1 Chi J Int'l L 101, at 107-8. While this article does discuss the absence of voice from various parts of the world, interestingly this special edition of the Chicago Journal of International Law (which asked the question of what was wrong with international law at the turn of the last century) did not identify subaltern issues or feminism, though it did mention critical legal studies. 
consideration of feminist perspectives, sexuality and subaltern discussions of law are not, as yet, mainstream and the dominance of Euro-American scholarship has long been acknowledged ${ }^{42}$ These absences are beside the relative non-existence of discussion of disability or sexual orientation, beyond a human rights approach, within international law ${ }^{43}$

Gleider Hernández's paper mentioned the educational background of ICJ judges and their rather narrow pool of educational geography ${ }^{44}$ Thus, the emphasis on 'geographical spread' in guidelines on appointment does not necessarily equate to a variety of opinion if all the voices come from the same sub-group of legal-educational backgrounds. Such narrowness among Schachter's 'invisible college of international lawyers' incurs a responsibility to ensure that an 'old-boy' network does not strangle debate or, at the very least, restrict its parameters ${ }^{45}$ Bordieu's work on the demographics of French academia in the 1980s highlighted the possibility of narrowness amongst the sistren and brethren of academia. While advances have been made within international law, such issues of participation remain critical in a genre that claims to be 'universal ${ }^{46}$

42 A. Anghie, Imperialism, Sovereignty and the Making of International Law (Cambridge University Press, 2007), B. S. Chimni, 'The Past, Present and Future of International Law: A Critical Third World Approach', (2007) 8 MJIL 499, M. Koskenniemi 'International Law in Europe: Between Tradition and Renewal' (2005) 16(1) EJIL 113, O. Yasuaki, 'When Was the Law of International Society Born? - An Inquiry of the History of International Law from an Intercivilizational Perspective', (2000) 2 Journal of the History of International Law 1, D. Otto, 'The Exile of Inclusion: Reflections on Gender Issues in International Law over the Last Decade', (2009) 10 MJIL 11, P. Berman, 'Power and Irony, or, International Law after the Après-Guerre' in E. Jouannet, H. Ruiz Fabri and J. M. Sorel (eds.), Regards D’Une Génération de Juristes Sur Le Droit International (Editions A Pedone, 2008) 79, F. Tesón, 'Feminism and International Law: A Reply', (1997) 33 VJIL 647, H. Charlesworth, 'Talking to Ourselves? Feminist Scholarship in International Law' in S. Kuovo and Z. Pearson, Feminist Perspectives on Contemporary International Law: Between Resistance and Compliance? (Hart, 2011) 17. Though some do disagree and argue feminism is in the mainstream: see D. Buss and A. Manji, 'Introduction' in D. Buss and A. Manji (eds.), International Law: Modern Feminist Approaches (Hart, 2005) 13.

43 M. J. Roseman and A. M. Miller, 'Normalizing Sexuality and its Discontents', (2011) 34 Harvard Journal of Law and Gender 313.

44 The election of Judge Sebutinde to ICJ broadens this slightly, while maintaining the small number of countries in which the judge's postgraduate education took place.

45 O. Schachter, 'Invisible College of International Lawyers', (1977-1978) 72 Nw U L Rev 217.

46 H. Grotius, De Jure Belli ac Pacis (1625), G.C. Marks, 'Indigenous Peoples in International Law: The Significance of Francisco De Vitoria and Bartolome De Las Casas', (1990-1991) 3 Australian Yearbook of International Law 1, J. I. Charney, 'Universal International Law', (1993) 87 AJIL 529. 
Sands' discussion of Lauterpacht and Lemkin emphasised the importance of two individuals within international legal academia who studied at, in today's world view, a university that does not figure at the top of global league tables ${ }^{47}$ emphasising the need to perhaps look beyond the more famous law schools when populating speaker guest-lists, particularly keynote speakers. This becomes increasingly important as the range of students travelling across the globe increases considerably and awareness of developments in regional legal systems become ever more pertinent to our understanding of international law ${ }^{48}$ Indeed, Cançado Trindade's comments on the Inter-American Court are one example of how generalisations about international law can by vastly inaccurate and the inclusion of such knowledge ever more pertinent to remedy its prior absence ${ }^{49}$ The geographical and economic difficulties associated with global participation in events remains a barrier but one, due to advances in technology, which is not insurmountable.

The same faces continually recurring at every conference potentially closesoff a genuine opportunity for active academic engagement. These kinds of conferences, which generally fall into the first category of 'like-minded' events, risk slipping into a reunion for the well-known to rehash the same argument, in different guises, that they have been having for several years. Obviously, when this frequent argument is fundamental to our understanding of international law or has changed fundamentally over a period, then perhaps this repetition remains worthwhile, but when conferences simply become a circuit with the same faces plus any additions to the cast-list, they vastly undermine the purpose and worth of holding such events. Thus, beyond the simple importance and arguments for inclusion, which are in themselves arguably sufficient, lies the importance of not re-hashing the same circuit for the entirety of academic careers. In its place, a much more diversely populated conference could bring a more thoughtful and engaging event to the fore, and contribute to international legal academia as a more contemplative and motivating space.

47 University of Lviv.

48 According the Higher Education Statistics authority in 2010/2011 there were a total of 428,225 international students (including EU) studying in the UK: <http://www.hesa.ac.uk/content/view/1897/239/> [last accessed 8 August 2012]. According to the OECD in 2009, there were 3.7 million tertiary international students studying worldwide: OECD, Education at a Glance 2011, <http://www.oecd-ilibrary.org/educa tion/highlights-from-education-at-a-glance_2076264x;jsessionid=13k95r2aep4ws.delta> [last accessed 12 August 2012].

49 Bourdieu's consideration of the demographic make-up of French academia suggests the variety of capital which various groups possess and the impact upon academic debate. See Bourdieu, supra note 3, see also Cownie's discussion of the impact of Bourdieu and 'capital'. 
As this article was written, the author received an email detailing a law conference to be held in London, of which, among the ten speakers, there was but one woman discussing equality. All other speakers were white men. Frustration which builds from continuously being confronted by such homogeneity among panels and keynote speakers remains present, and the Cambridge organisers are to be commended that only one panel was all-male and a broad spectrum of nationalities were present both on panels and in the audience. Unfortunately, there was but one woman, besides Rumiana Yotova as editor and organiser, who addressed the conference from beyond a panel, and there were no female keynote speakers ${ }^{50}$ Given that it is not that long since Judge Higgins in 1995 was the first female member of the ICJ.51 and it was not until 2002 that the International Law Commission (ILC) possessed any female members, rather large representational gaps remain within international law ${ }^{52}$ Several recent high-profile appointments such as Nkosazana Dlamini Zuma as Chair of the African Union, Christine Lagarde as Managing Director of the IMF and Fatou Bensouda as Chief Prosecutor at the ICC suggest progress regarding women's participation in international law. Nonetheless, as international lawyers writing with a feminist critique have continued to point out, the ever-present inequality regarding women's participation within international law and academia remains steadfast ${ }^{53}$ As important offices within international law are often filled from academic ranks, participation at conferences remains

50 See further <http://feministlawprofessors.com>, <http://www.intlawgrrls.com>, $<\mathrm{http}$ //www.good.is/posts/why-white-men-should-refuse-to-be-on-panels-of-all-white$\mathrm{men} />$, <http://feministphilosophers.wordpress.com/2011/01/03/gendered-conferencecampaign-letter/>, <http://beingawomaninphilosophy.wordpress.com/ $>$ [all last accessed 8 August 2012].

51 More recently, Judge Julia Sebutinde became the fourth female permanent member of the Court. Suzanne Bastid was a judge ad hoc in the Case Concerning the Continental Shelf (Tunisia $v$ Libyan Arab Jamahiriya) Judgment, ICJ Reports 1985, p. 192. Bastid was also the first female Chair in International Law in France, and possibly anywhere, in 1946. In contrast, the International Criminal Court's balance is currently actually in favour of women, with ten of the eighteen judges being women, suggesting that both seniority and expertise among women in international law is available, if simply not chosen. Further, the 1998 Statute of the International Criminal Court, 2187 UNTS 90 Art. 36 (8)(a)(iii) requires 'a fair representation of female and male judges' without a specific quota, which assists in ensuring states both put forward and select women.

52 Paula Escarameia and Xue Hanqin, now at the ICJ, were appointed to the ILC in 2002 and they were joined by Marie G. Jacobsson in 2007 and Concepción Escobar Hernández in 2011. There are currently two women serving on the 34 person Commission.

53 S. B. Boyd, 'Spaces and Challenges: Feminism in Legal Academia', (2011) 44 UBC Law Review 205, F.C. Cownie, 'Dressing the Part: Gender, Performance and the Culture of Law Schools', (2006) 57 NILQ 557. 
a critical path of development, and nurturing of new female talent to ensure that women are cemented as agents of change in a universal international law is important.

Particularly as presence in itself does not necessarily lead to an appreciation or active participation a quota system, ensuring every panel possesses a correct mix at each academic conference is not at the forefront of suggested proposals herein 54 Nonetheless, this paper suggests that the customary response that there are simply no available individuals in an area of debate is insufficient $5_{55}^{55}$ This oft-proffered explanation-that nobody senior enough for a keynote address exists, or was available for a conference, or nobody replied to the call for papers-has become feeble. Remarkably, this lack of availability never becomes an issue for white male academics who are always available and invariably specialists in a given field ${ }^{56}$ Given the percentage of female to male undergraduates, it does suggest that if there are no women available with seniority or experience, there are other accompanying issues, including, perhaps, a lack of female role models showcased at conferences ${ }^{57}$ The absence of an ethnically diverse academy which leads to the same rationale being proffered also stems from similar problems within academia itself.

Possible remedies to move away from homogeneity include the spreading of calls for papers more widely and targeting the calls by sending them to individuals, law schools, groups or organisations which possess a more ethnically and gender diverse faculty. Panels could also be put together that remain coherent, but also representative of those affected by international

54 See for example, Human Rights Council, 'Recommendations of the Forum on Minority Issues at its Fourth Session: Guaranteeing the Rights of Minority Women and Girls (29 and 30 November 2011)', UN Doc. A/HRC/19/71 (2012), M. Weller and K. Nobbs (eds.), Political Participation of Minorities: A Commentary on International Standards and Practice' (Oxford University Press, 2010) particularly I. Klímová-Alexander, 'Effective Participation by Minorities: United Nations Standards and Practice' at 286.

55 L. Penny, 'So, it Turns Out Feminism is a CIA Plot to Undermine the Left', New Statesman, 29 February 2012 <http://www.newstatesman.com/blogs/laurie-penny/2012/02/womenwhite-miller-woman-young-2> [last accessed 23 October 2012].

56 M. E. Kornhauser, 'Rooms of Their Own: An Empirical Study of Occupational Segregation by Gender Among Law Professors', (2005) 73 UMKC Law Review 293, D. L. Rhode, The Beauty Bias: The Injustice of Appearance in Life and Law (Oxford University Press, 2010), D. L. Rhode, 'Midcourse Corrections: Women in Legal Education', (2003) 53 Journal of Legal Education 475, C. M. S. McGlynn, 'Women, Representation and the Legal Academy', (1999) 19 Legal Studies 68.

57 S. Bashi and M. Iskander, 'Why Legal Education is Failing Women', (2006) 18 Yale LJ $\&$ Feminism 389, L. Guinier, M. Fine and J. Balin, 'Becoming Gentlemen: Women's Experiences at One Ivy League Law School', (1994) 143 U Pa L Rev 1. 
law. Another solution includes the embracing of communication technology. Advancements, particularly over the past decade, lends powerful support to the use of various electronic media to engage with academics who cannot attend a particular event in person, due to geographical, situational, caring, political or disability access. In places, the natural geographic and, importantly, economic, hindrances upon academic debate and participation can be ameliorated in ways which could not be envisaged even a decade ago. That being said, the importance of academics engaging in person should not be underestimated, but where a broader range of perspectives can be brought together through the use of technology, such opportunities should not be ignored.

Organisers maintain a full command of structure and participation at invitation-only events, thus engaging a responsibility to ensure wide participation among their speakers and audiences. These closed events posses the possibility to be academically dynamic, but also in having a small breadth of contribution, risk furthering narrowness within academia. Yet perhaps the greatest responsibility lies with the selection of keynote speakers for both open and invitation conferences. Ensuring, particularly when there are a number of individuals giving addresses, that they are not homogenous, should be an imperative organisational issue. Without such efforts, it is doubtful that the 'engagement' conference can ever fully take place, and what will be left is a group talking amongst themselves, excluding a wider academic audience from becoming agents of change, engaging in the spirit of debate which the Cambridge conference, in many ways, exemplified.

\section{Conclusion}

International legal academia, perhaps more than any other area of scholastic legal study, engages directly with the practice and development of law. Academics contribute through parallel practice, positions on courts and tribunals, advisory boards, contributions to reports and inquiries amongst other roles, to the system of international law. Importantly, however, academics also participate within international law as contributors to law in their capacity as scholars. The acknowledgement of their place within the ICJ Statute epitomises the importance of the individual academic as a potential agent of change and as a participant within the international legal system.

The implications and impact of individuals as agents and participants was at the heart of the Cambridge conference, and brought to the fore the importance of keeping the role of the individual in mind when considering international 
law's development and operation. While there may not necessarily have been agreement on the individual as actor, subject or object of international law, there was recognition that international law is developing away from its several-century existence as a state-bound system.

The Cambridge conference enabled a number of dialectical exchanges, such as those between Crawford and Cançado Trindade, echoing Sands' consideration of Lemkin and Lauterpacht, and re-emphasised the importance of non-state interactions, which arguably only conferences can command. While an academic's written pieces stand as testament to her work, conferences enable a lively and engaged dialogue that moves an argument in an active, though perhaps not always progressive, fashion. Nonetheless, as this article has emphasised, this vigorous character can only be achieved if both organisers and participants are serious in their attempts to ensure participation is open, taking active steps to guarantee that academics engage in an open and positive fashion, and further take the opportunity to 'meet' in a constructive fashion within the academic collective. This may require positive steps to be taken by organisers to ensure this occurs, but such steps would be worthwhile. 